\title{
Manajemen Peserta Didik Profesional Dalam Praktik
}

\author{
Muhasim \\ STIT Palapa Nusantara Lombok NTB \\ mhmsaidah@gmail.com
}

\begin{abstract}
Abstrak: Manajemen peserta didik haruslah terlebih dahulu memahami tentang manajemen baik pendapat ahli maupun secara etimologis. Dalam pengertian secara umum manajemen sebagai salah satu sistem fungsi-fungsi serta pemanfatan unsur-unsur manajemen dalam organisasi. Pendapat lain memandang manajemen sebagai Ilmu dan Seni, sebagai proses sosial yang memandang fungsi perencanaan, fungsi pengorganisasian, fungsi penggerakan dan fungsi pengawasan sebagai sebuah siklus. Sebagai proses yaitu dengan melihat fungsi Perencanaan merupakan sebuah keputusan dalam mengaplikasikan fungsi manajemen lainnya. Proses fungsi-fungsi manajemen tersebut sekaligus mengatur hubungan antar fungsi dan akan menjadi gambaran fleksibilitas fungsi perencanaan sebagai sebuah awal pengoganisasian, penggerakan dan pengawasan. Dalam pengertian manajemen sebagaimana diuaikan diatas, maka manajemen peserta didik dapat diartikan sebagai usaha pengaturan terhadap peserta didik mulai dari peserta didik tersebut masuk sekolah sampai dengan mereka lulus sekolah. Manajemen peserta didik memusatkan perhatian pada perencanaan, pengaturan, pengawasan dan layanan siswa di kelas dan di luar kelas seperti: pengenalan, pendaftaran, layanan individual seperti pengembangan keseluruhan kemampuan, minat, kebutuhan sampai ia matang di sekolah. Dalam perospektif peseta didik memiliki berbagai macam harapan yang harus dapat diwujudkan ketika mereka telah menamatkan pendidikannya di jenjang persekolahan. Prospektif peserta didik akan berhasil sebagaimana dihajatkan, jika manajemen peserta didik dikelola secara profesional. Pofesional guru dalam pembentukan sikap selain seperangkat kompetensi peserta didik sehingga memiliki Ilmu pengetahuan, dan skill. Untuk mengkaji secara komplek metode yang digunakan dalam tulisan ini, yaitu metode deskriptif artinya memahami apa yang menjadi objek tulisan, mencermati berbagai situasi dan realitas sosial yang ada di masyarakat dari berbagai sumber yang dapat dipercaya, tulisan, media online yang sesuai objek tulisan. Dengan metode tersebut ditemukan bagaimana pentingnya manajemen peserta di-
\end{abstract}


dik profesional dalam praktik, dalam mencetak peserta didik yang memiliki kompetensi sebagaimana yang dihajatkan oleh peserta didik itu sendiri dan lembaga pendidikan dimana peserta didik tersebut belajar.

Kata Kunci: Manajemen, Peserta Didik, Profesional dalam Praktik.

\section{Management Of Professional Learners In Practice}

Abstract: Student management must first understand the management of both expert opinion and etymologically. In the general sense management as one of the system functions and utilization of elements of management within the organization. Another view views management as Science and Art, as a social process that views the functions of planning, organizing functions, mobilizing functions and oversight functions as a cycle. As a process that is to see the function of Planning is a decision in applying other management functions. The process of these management functions simultaneously regulates the relationships between functions and will serve as an overview of the flexibility of the planning function as an early organizing, moving and monitoring. In terms of management as described above, the management of learners can be defined as an effort to regulate the learners from the students enter the school until they graduate school. Student management focuses on the planning, arrangement, supervision and service of students in the classroom and beyond the classroom such as: recognition, enrollment, individual services such as the development of the overall skills, interests, needs until it matures in school. In prospective learners have a variety of expectations that must be realized when they have finished their education at the level of schooling. Prospective learners will succeed as required, if the management of learners is professionally managed. Professional teachers in the formation of attitudes as well as a set of competence learners that have knowledge, and skills. To examine the complexity of the method used in this paper, the descriptive method means to understand what the object of writing, to observe the various situations and social realities that exist in the community from various sources that can be trusted, writing, online media that match the object of writing. With this method found how important the management of professional learners in practice, in printing learners who have competencies as dictated by the learners themselves and educational institutions where learners are learning.

Keywords: Management, Learners, Professional in Practice. 


\section{Pendahuluan}

Frofesional pendidik merupakan hal yang penting karena hal tersebut dapat meningkatkan kemampuan dan kompetensi pendidik yang nantinya akan dapat memperbaiki secara terus menerus proses pembelajaran dan akan bermuara pada output yaitu peningkatan prestasi peserta didik. Untuk hal tersebut pemerintah juga ikut campur tangan, salah satunya seperti memberikan sertifikasi kepada pendidik. Permasalahannya apakah dengan sertifikasi profesional pendidik dalam praktik mengajar akan meningkat. Itulah sebabnya perlu dirangkaian dengan kemampuan menejrial yang menyangkut menejemen peserta didik.

Berbicara tentang manajemen haruslah dengan memahami pengertian manajemen baik secara etimologis maupun terminologis dengan mengungkapkan seoptimal mungkin pendapat para ahli dibidang manajemen. Manajemen menurut George R.Terry alih bahasa oleh Winardi mengatakan bahwa manajemen adalah tindakan memikirkan dan mencapai hasil-hasil yang diinginkan melalui usaha kelompok yang terdiri dari tindakan mendayagunakan bakat-bakat manusia dan sumber-sumber daya. .

Titik beratnya memandang manajemen usaha memikirkan dan melakukan tindakan untuk mendayagunakan bakat-bakat dan sumber daya. Melakukan tindakan dan mendayagunakan bakat dengan memanfaatkan sumber daya, akan lebih efektif jika melalui proses fungsi-fungsi manajemen. Proses yaitu dengan melakukan fungsi perencanaan, fungsi pengorganisasian, fungsi penggerakan dan fungsi pengawasan. Oleh karena para ahli manajemen memandang manajemen sebagai salah satu sistem dalam organisasi. Perencanaan dipandang sebuah keputusan dalam mengaplikasikan fungsi pengorganisasian, penggerakan dan pengawasan. Proses fungsi-fungsi manajemen tersebut sekaligus mengatur hubungan antar fungsi dan akan menjadi gambaran fleksibilitas fungsi perencanaan dalam organisasi.

Kaitannya dengan manajemen peserta didik dapat diartikan sebagai usaha pengaturan terhadap peserta didik mulai dari peserta didik tersebut masuk sekolah sampai den-

${ }^{1}$.George R.Terry alih bahasa DR.Winardi,SE, Asas-Asas Manajemen, Penerbit,Alumni Bandung,Tahun $1986,5$. 
gan mereka lulus sekolah. Manajemen peserta didik memusatkan perhatian pada perencanaan, pengaturan, pengawasan dan layanan siswa di kelas dan di luar kelas seperti: pengenalan, pendaftaran, layanan individual seperti pengembangan keseluruhan kemampuan, minat, kebutuhan sampai ia matang di sekolah.

Dalam prospektif peseta didik memiliki berbagai macam harapan yang harus dapat diwujudkan ketika mereka telah menamatkan pendidikannya di jenjang persekolahan. Prospektif peserta didik tersebut akan dapat terbuktikan jika, manajemen peserta didik dikelola secara profesional. Pofesional dalam pembentukan sikap selain seperangkat kompetensi meliputi Ilmu pengetahuan dan skill. Memang dalam menafsirkan makna profesional, ada pendapat yang selalu mengaitkan dengan uang. Artinya semakin baik profesionalisme seseorang, semakin mahal nilai jual jasa yang akan disumbangkan pada sebuah organisasi. Seharusnya tidak selamanya demikian, tetapi semakin baik profesional seseorang semakin maksimal mereka bekerja dengan penuh komitmen dan kesungguhan. Oleh karena istilah profesional merupakan karakter yang melekat pada pendidik, sebagaimana ditetapkan dalam Undang-undang Sistem Pendidikan Nasional bab IX pasal 39 ayat 2: Pendidik merupakan tenaga profesional yang bertugas merencanakan dan melaksanakan proses pembelajaran, menilai hasil pembelajaran, melakukan pembimbingan dan pelatihan, serta melakukan penelitian dan pengabdian kepada masyarakat, terutama bagi pendidikan pada perguruan Tinggi. ${ }^{2}$

Itulah yang kita harapkan dengan menajemen peserta didik profesioal dalam praktik, yaitu praktik manajemen peserta didik profesional harus dapat diaplikasikan dalam praktik belajar mengajar seorang pengajar baik itu dalam jenjang pendidikan dasar sampai ke tingkat Perguruan Tinggi. Menyebut peserta didik untuk membuatnya lebih umum, dibanding dengan menyebut murid, karena sebutan murid hanya terdapat dalam sekolah Disampai Sekolah menengah, tidak termasuk Mahasiswa, tetapi dengan identitas peserta didik dapat melingkupi dari Sekolah Dasar sampai Perguruan Ting-

2. https://www.kompasiana.com/ianmursito/profesionalisme-guru-sebagai-indikator-keberhasilandalam-peningkatan-prestasi-belajar-siswa_576207d964afbdf5038b457e 
gi. Dengan demikian akan dapat membantu kita dalam menggunakan istilah serta membahas manajemen peserta didik, professional dalam praktik.

\section{Landasan Teori}

Manajemen Berdasarkan beberapa pengertian Manajemen secara Etimologis berasal dari bahasa Inggris yaitu dari kata kerja " to manage " yang sinonimnya antara laian " to hand " berarti mengurus, "to control " memeriksa, " to guide " memimpin. Jadi, bila dilihat asal katanya katanya manajemen dapat diartikan sebagai : mengurus, mengatur, melaksanakan dan menge lola. Sementara di Indonesia menurut Uberet Silalahi dikenal dengan kata manajemen/managemen yang diterjemahkan ke dalam berbagai istilah seperti kepemimpinan, tata cara memimpin, pengaturan, pengelolaan, pengendalian, pengurusan, pembinaan, penguasaan dan lain sebagainya. ${ }^{3}$.

K.H.Toto Tasmara, menyebut manajemen berasal dari kata "Manus-tangan" yang berarti menangani sesuatu, mengatur, membuat sesuatu menjadi sesuai dengan yang diinginkan. ${ }^{4}$.

Menurut Nanang Fatah mengemukakan bahwa manajemen sering diartikan sebagai ilmu, kiat dan profesi. Manajemen dipadang sebgai sutau bidang pengetahuan yang secara sistematis berusaha memahami mengapa dan bagiamana orang bekerja sama. ${ }^{5}$

A.W. Widjaya mengemukakan bahwa manajemen adalah proses atau usaha bersama orang-orang guna mencapai suatu tujuan yang tlah ditetapkan. ${ }^{6 .}$

\section{Peserta Didik}

Peserta didik merupakan bagian dalam sistem pendidikan, peserta didik adalah objek atau bahan mentah dalam proses transformasi pendidikan. Tanpa adanya peserta didik, keberadaan sistem pendidikan tidak akan berjalan. Karena kedua faktor antara

3. Ramayulis dan Mulyadi, Manajemen \& Kepemimpinan Pendidikan Islam (Jakarta: Kalam Mulia 2017), 23.

4. Toto Tasmara, Spiritual Centered Leadership, Penerbit (Jakarta: Gema Insani, 2006), 191.

5. Ibid, Ramayulis, 23.

6 . Ibid, 23. 
pendidik dan peserta didik merupakan komponen paling utama dalam suatu sistem pendidikan. $^{7}$

Secara bahasa peserta didik adalah orang yang sedang berada pada fase pertumbuhan dan perkembangan baik secara fisik maupun psikis, pertumbuhan dan perkembangan merupakan ciri dari seseorang peserta didik yang perlu bimbingan dari seorang pendidik. Pertumbuhan yang menyangkut fisik, perkembangan menyangkut psikis.

Pengertian peserta didik menurut UU RI No: 20 Tahun 2003 tentang Sistem Pendidikan Nasional adalah anggota masyarakat yang berusaha mengembangkan potensi diri melalui proses pembelajaran yang tersedia pada jalur, jenjang dan jenis pendidikan tertentu. ${ }^{8}$.

Menurut Wahjosumirdjo, hak-hak peserta didik secara individual harus dilindu ngi dan kebutuhan pendidikan mereka harus dipenuhi. ${ }^{9}$

Abu Ahmadi berpendapat bahwa peserta didik adalah sosok manusia sebagai individu / pribadi (manusia seutuhnya). Individu diartikan orang seorang yang tidak tergantung dari orang lain, dalam arti benar-benar seorang pribadi yang menentukan diri sendiri dan tidak dipaksi dari luar, mempunyai sifat-sifat dan keinginan sendiri. ${ }^{10}$

\section{Manajemen Peserta Didik}

Harold Koontz dan Cryil O’Donel mendefinisikan manajemen peserta didik sebagai usaha untuk mencapai suatu tujuan tertentu melalui kegiatan orang lain. Dengan demikian Manajer mengadakan koordinasi atas sejumlah aktivitas orang lain yang meliputi perencanaan, pengorganisasian, penempatan, pengarahan dan pengendalian. ${ }^{11}$.

7 Tim Adminstrasi Pendidikan Universitas Pendidikan Indonesia, Manajemen Pendidikan, Penerbit Al pabeta, Bandung, Tahun 2012, 204.

8. Ibid, 204.

9. Ramayulis dan Mulyadi, Manajemen.., 125.

10 . Ibid, 205.

11 . Ibid, 204. 
Hadiyanto, berpendapat bahwa manajemen Peserta didik adalah proses pengaturan kegiatan dari hal-hal yang berhubungan dengan peserta didik untuk mencapai tujuan pendidikan. ${ }^{12 .}$

Dr.Eka Prihatin, M.Pd, menyebut manajemen peserta didik dapat diartikan sebagai usaha pengaturan terhadap peserta didik mulai dari peserta didik tersebut masuk sekolah sampai dengan mereka lulus sekolah. ${ }^{13}$

\section{Profesional.}

Profesi adalah kata serapan dari sebuah kata dalam bahasa Inggris "Profess", yang

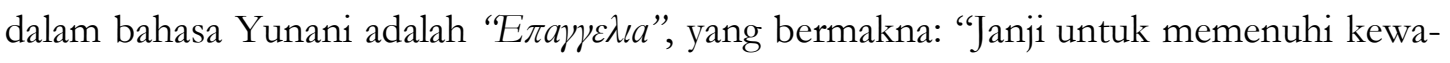
jiban melakukan suatu tugas khusus secara tetap/permanen”. Seseorang yang memiliki suatu profesi tertentu, disebut profesional. Walaupun begitu, istilah profesional juga digunakan untuk suatu aktivitas yang menerima bayaran, sebagai lawan kata dari amatir. Contohnya adalah petinju profesional menerima bayaran untuk pertandingan tinju yang dilakukannya, sementara olahraga tinju sendiri umumnya tidak dianggap sebagai suatu profesi. How pro the professional?" menjadi seorang profesional berarti dia berhasil menguasai ilmu dari orang lain yang lebih hebat darinya, jadi profesional adalah apabila seseorang menguasai ilmu dari orang lain yang lebih hebat dari dirinya ${ }^{14}$

David H. Maister, mengatakan makna profesionl itu bekerja dengan maksimak dan penuh komitmen dan kesungguhan. ${ }^{15}$

Louis Allen manajemen profesional adalah system dalam organisasi yang memungkinkan berjalannya fungsi-fungsi manajemen yaitu planning, organizing, leading dan kontroling. ${ }^{16}$

\section{Manajemen Peserta Didik.}

12. Ramayulis, dan Mulyadi, 125.

13. Dr.Eka Prihatin, M.Pd, Manajemen Peserta Didik, Penerbit Alpabeta, Bandung, Tahun 2014, halaman 4.

14. https://azenismail.wordpress.com/2013/06/04/pengertian-profesi-dan-profesionalisme/

15. https// Library.walisongo.ad.id "Manajemen Profesionl " (online ), diakses 27, Desember 2017.

16. Ibid, // Library.walisongo.ad.id “ Manajemen Profesionl “ ( online), diakses 27, Desember 2017. 
Manajemen berdasarkan pendapat para ahli banyak diterjemahkan dengan istilah yang berbeda-beda, namun tidak lain mengandung makna merencanakan, mengorganisir, menggerakakan dan melakukan pengawasan atas apa yang sudah direncanakan, disebut fungsi manajemen. Fungsi-fungsi tersebut mempunyai rangkaian dan bersinergi antara fungsi yang satu dengan lainnya, artinya bahwa tidak bisa suatu fungsi perencanaan saja berjalan sendiri, tentu perlu diorganisir dalam pelaksanaannya, selanjutnya atas tiga fungsi tersebut perlu diawasi. Hasil pengawasan akan menjadi input atau masukan untuk memperbaiki atau menyempurnakan perencanaan, sehingga dengan demikian akan terjadi pengembangan perencanaan dan fungsi yang lain, sehingga akan tercipta kemajuan untuk mencapai tujuan organisasi yang sudah ditentukan sebelumnya.

Fungsi- fungsi manajemen tersebut tidak terlepas dari perkembangan Ilmu dan profesi sebagaimana dikemukan oleh Nang Fatah, maka sebagai Ilmu akan terus seirama dengan kamajuan pengetahuan manusia dan tehnologi. Dewasa ini tehnologi seperti komputer, Internet dan media elektronik lainnya, sudah mempengaruhi cara kerja manajemen menjadi lebih mudah, lebih praktis dan lebih cepat. Demikain juga akan mempengaruhi manajemen peserta didik. Peserta didik selain sebagai Objek juga subjek, kaitannya dengan peserta didik sebagai objek dimana peserta didik merupakan bahan menal dari transformasi pendidikan. Tanpa adanya peserta didik, sistem pendidikan tidak akan berjalan, peserta didik sama pentingan dengan pendidik sebagai subjek.

Peserta didik orang yang sedang berada pada fase pertumbuhan dan perkembangan baik secara fisik maupun fsikis, melalui pembelajaran. Sebagaimana dikemukan juga dalam UU Nomor : 20 Tahun 2003, tentang Sistem Pendidikan Nasional. Kaitannya dengan peserta didik sebgai Objek, sebagaimana dikemukan oleh Wahjosumirdjo, dimana hak-hak peserta didik secara individual harus dilindungi dan kebutuhan peserta didik harus dipenuhi. Sebagai subjek peserta didik harus didik untuk memiliki kemandirian, istilah umum peserta didik datang kesekolah untuk mencari ilmu bukan menuntut ilmu. Kalau menuntut ilmu maknanya perserta didik hanya menunggu apa yang dusuguhkan dalam ceramah-ceramahnya oleh pendidikan, sehingga peserta didik datang disekolah hanya mendengarkan ceramah, setelah itu pulang, tetapi kalau mencari ilmu pe- 
serta didik itu, sebagai seorang yang tidak tergantung dari luar, mempunyai sifat-sifat dan kinginan sendiri, memiliki motivasi dan kreasi untuk mengembangkan dirinya.

Makna peserta didik untuk mencari ilmu untuk pengembangan diri secara pribadi baik fisik maupun fsikis, hal itu tergantung profesionalisme pendidik dalam menjalankan praktik mengajar, sehingga makna manajemen peserta didik sebagaimana dikemukan oleh Harold Koontz dan Cryl O’Donel, adalah sebagai usaha untuk mencapai tujuan tertentu melalui kegiatan orang lain akan tercipta.

Peserta didik adalah makhluk yang sedang berada dalam proses perkembangan dan pertumbuhan menurut fitrahnya masing-masing. Peserta didik memerlukan bimbingan, arahan dan petunjuk, secara konsisten arah titik optimal kemampuan fitrahnya. Peserta didik tidak hanya dianggap sebagai objek, melainkan harus perlakukan sebagai subjek pendidikan. Karena hal ini dilakukan dengan cara melibatkan mereka dalam memecahkan masalah dalam proses belajar mengajar. Oleh karena itu hubungan antara peserta didik dan pendidik termasuk proses pendidikan, dimana pendidik harus mengatur kegiatan yang berhubungan dengan peserta didik, dari mulai peserta didik masuk sekolah sampai dengan mereka lulus sekolah, sehingga tujuan pendidikan dapat tercapai, hal ini tidak sesederhana yang dikatakan tetapi membutuhkan profesionalime pendidik dalam menjalankan praktik mengajar.

\section{Profesional Dalam Praktik.}

Profesional menurut pendapat ahli bertumpu pada proses manajemen dalam suatu organisasi, artinya bahwa setiap person organisasi berupaya efektif untuk menjalan fungsi-fungsi manajemen. Mereka disebut profesional karena mereka memiliki ilmu yang layak menyandang predikat rofesional. Profesional asal kata profesi yaitu komitmen untuk melakukan suatu tugas khusus secara tetap atau permanen. Guru mempunyai predikat rofesi, karena ia memiliki ilmu dan kompetensi, sehingga Guru layak dimasukkan dalam kelmpok professional. Seorang yang profesional artinya ia memiliki ilmu yang dapat dipraktikkan kepada klien, kalau guru sekolah kliennya adalah peserta titik, dokter kliennya adalah masyarakat yang memerlukan pengobatan, pengacara kliennya adalah 
masyarakat yang memerlukan bantuan Hukum, notaris dan banyak lagi orang-orang yang lain yang termasuk kelompok profesional yang tidak bisa di sebutkan secara rinci dalam kesempatan ini.

Para profesional mereka mempraktikan ilmu yang dimiliki secara tetap atau permanendemikian juga halnya dengan guru. Mereka memiliki teori, metode, model sebagai teori yang akan dipraktikkan dalam mengajar peserta didik dengan baik dan terukur, sehingga menghasilkan pendidikan bagi peserta didik sesuai dengan yang diharapkan peserta didik dan lembaga pendidikan . Alatnya ukurnya adalah kurikulum, sekarang ini guru tidak saja ceramah tetapi bagaimana guru menggunakan metode yang dapat mendorong peserta didik untuk belajar, peserta didik datang kesekolah buka saja menuntut ilmu tetapi mencari ilmu. Oleh karena itu guru harus profesioanal membimbing , merencanakan, mengorganisasikan, memotivasi peserta didik agar lebih aktif belajar selain medengarkan.

Pendidik kaya akan teori yang akan dipraktikan dalam memberikan pelajarannya tinggal bagaimana kecerdasan pendidik merencanakan penggunaaan teori mempedomani kurikulum dan mengatur metode mengajar. Harus diingat bahwa guru akan menghadapi peserta didik yang memiliki karakter dan latar belakang kehidupan yang berbeda, yang tentu untuk mengatur metode belajar menjadi tumpuan dan praktik mengajar. Lebih lagi sekarang ini disebut zaman tehnologi modern, yang kadang-kadang setiap peserta didik masing-masing sibuk dengan telpon genggamnya ( HP ). Jika pendidik tidak professional menghadapi perkembangan tersebut akan mengganggu ketentraman dan konsentarasi peserta didik dalam menerima pelajaran.

Gangguan yang yang muncul disebabkan ganguan dari peserta didik baik dengan HP maupun dengan kondisi latar belakang peserta didik, itu bukan tantangan tetapi sebagai penambah ikhtiar untuk menyempurnakan perencanan, pengorganisasian, pelaksanaan dan pengawasan dalam meningkatkan profesionalisme dalam praktik mengajar. Bagi pengajar yang profesional, dia akan dapat memanfaatkan tehnologi modern itu sebagai penujang belajar peserta didik. Tehnologi dapat dimanfaatkan sebagai media penunjang, karena media tersebut dapat mempermudah, mempercepat untuk mempero- 
leh materi pelajaran, melalui Internet, cukup dengan mengklik google.com, apa yang dibutuhkan akan muncul. Praktis, cepat, namun pengaruh negatifnya juga tidak bisa diabaikan, karena kecerdasan orang-orang yang jahat, ketika kita mengklik google.com, yang muncuk justru gambar-gambar yang tidak layak dilihat sama peserta didik. Oleh karena manajemen peserta didik profesional dalam praktik, harus dikuasi oleh setiap pengajar.

\section{Manajemen Peserta Didik Profesional Dalam Praktik.}

Menurut pengertian para ahli di atas dapat disimpulkan bahwa manajemen peserta didik adalah kegiatan yang dilakukan melalui proses manajemen melalui proses fungsi manajemen yaitu perencanaan, pengorganisasian, penggerakan dan pengawasan. Dalam proses dengan memanfaatkan tenaga orang lain untuk mencapai tujuan tertentu. Namun demikian manajemen peserta didik bekerja dalam sistem sehingga membuat tingkat profesional dalam praktik itu menjadi semakin baik. Membuat profesional itu menjadi semakin membaik, jika difungsikan fungsi-fungsi manajemen, yaitu perencanaan, pengorganisasian, penggerakan dan pengawasan, ibarat peredaran darah dalam tubuh manusia, semakin sehat fisik dan mental seseorang, semakin lancar peredahan darah, maka manusia akan semakin sehat. Hal tersebut dapat dijadikan contoh dalam mencetak peserta didik yang beriman, bertaqwa, berilmu pengetahuan, memiliki skill dan mampu secara komprehensif memanfaatkan ilmunya untuk masa depan mereka.

Manajemen peserta didik, profesional dalam praktik merupakan media yang handal untuk mencetak peserta didik menjadi sumber daya manusia yang berkualitas, beriman, bertaqwa, dan berhasil mengembangkan potensi dirinya melalui proses pembelajaran yng tersedia, sesuai tujuan Sistem Pendidikan Nasional, jika diselenggarakan secara professional. Manajemen peserta didik profesional dalam praktik, tidak sekedar melaksakan fungsi-fungsi manajemen, tetapi juga handal mengisi peserta didik dengan ilmu, membekali dengan pengetahuan, meningkatkan Iman dan taqwa serta skill. Mengisi peserta didik tersebut akan menjadikan peserta didik memiliki kompetensi dalam berbagai 
bidang ilmu dan pengayaan bahasa sehingga mampu menstarakan diri dengan tenaga kerja dari belahan Negara lain.

Sekarang ini perdagangan bebas baik ASEAN maupun MEA sudah tebuka, sehingga tidak mustahil sumber daya manusia dari Negara-negara bagian tersebut akan memasuki Negara Indonesia yang memiliki profesional yang mungkin lebih kompetitif. Disnilah pentingnya manajemen peserta didik profesional dalam praktik dijalankan oleh para pengajar, walaupun manajemen tidak berkaitan dengan untung rugi. Sisi lain manajemen tidak bisa pisah dengan kepemimpinan, karena tidak bisa kita bekerja hanya dengan kacamata manajemen, tetapi juga membutuhkan kompas untuk menentukan kiblat yang benar. Apalagi kita memahmi watak manusia itu berbebeda antar satu dengann lainnya, sehingga para pendidik dan tenaga kependidikan harus memiliki wawasan yang luas dan mampu mersakan suasana yang terjadi dalam dan luar lingkungan belajar siswa.

Menurut A.W.Widjaya ( 23 ).. manajemen adalah proses dari memimpin dan memberikan fasilitas dari usaha orang-orang yang terorganisasi di dalam organisasiorganisasi fungsional guna mencapai suatu tujuan yang telah ditetapkan. Manajemen peserta didik fungsinya untuk mamenej peserta didik, artinya mengatur, mengolah, mengurus dan mengawasi jalannya manajemen pendidikan apakah sudah para pengajar sudah profesional dalam praktik mengajar. Itulah maknanya manajemen bekerja dalam sistem untuk mengefektifkan kegiatan perencanaan, pelaksanaan, pemeriksaan, tindakan dan pengawasan peserta didik. Peserta didik adalah siapa saja yang terdaftar sebagai objek dan subjek didik dari suatu lemaga pendidikan baik dari semua tingkatan pendidikan dari tingkat Sekolah Dasar sampai ke Perguruan Tinggi.

Dengan demikian dapat disimpulkan bahwa manajemen peserta didik sebagai suatu usaha pengaturan terhadap peserta didik mulai dari proses rekrutmen sampai dengan peserta didik lulus atau keluar dari sekolahnya. Adanya manajemen peserta didik merupakan upaya untuk memberikan layanan yang sebaik mungkin kepada peserta didik semenjak dari prose penerimaan sampai pada saat peserta ddik meninggalkan lembaga pendidikan karena sudah tamat/lulus mengikuti lembaga pendidikan sekolah tersebut. Bahkan banyak sekarang, terutama sekolah-sekolah yan sudah maju dalam pelayanan 
peserta didik, meyiapkan antar jemput peserta didik dari rumah dan sekolah, inilah mungkin dapat dikelompokkan manajemen peserta didik professional dalam praktik. Menurut pengertian yang dikemukakan Abdul Mujib peserta didik cakupannya sangat luas, tidak hanya melibatkan anak-anak tetapi mencakup orang dewasa, melibatkan peran serta orang tua, campur tangan pemerintah. Jika kelompok yang harus berpartisipasi ini terwujud dalam sebuah sistem yang baku dan berkembang, maka manajemen peserta didik professional dalam praktik memperluas wawasannya, menjadi lebih komprehensip.Walaupun memang dalam ilmu pengajaran, pengajaran itu berpusat pada guru dan objek adalah peserta didik. Peserta didik mempunyai watak yang berbeda-beda, sebagai pengaruh watak, latar belakang keluarga, kondisi ekonomi dan budaya setempat, dalam hal ini fungsi manajemen peserta didik dalam profesional dalam praktik, menjadi semakin penting.

Berbicara masalah latar belakang peserta didik, sungguh mengundang banyak masalah yang dihadapi oleh seorang pendidik, namun mungkin tidak akan cukup kemampuan membahas secara keseluruhan, karena dibatasi kepustakaan, waktu, dan yang lebih penting lagi akan menjadi objek penulis lain, yang penting kita sudah dapat menyimpulkan bahwa manajemen peserta didik profesional dalam praktik, sangat penting dalam penyelenggaraan pendidikan danpengajaran, baik untuk mewujudkan tujuan peserta didik, institusi pendidikan dan tujuan Nasional pendidikan.

Peserta didik adalah klien utama yang harus dilayani, maka dari itu manajemen peserta didik mutlak perlu menjadi perhatian. Dari pengertian-pengertin teori diatas, bisa disimpulkan bahwa peserta didik adalah orang / pindividu yang mendapatkan pelayanan pendidikan sesuai dengan bakat, minat dan kemampuannya agar tumbuh dan berkembang dngan baik serta mempunyai kepuasan dalam menerima pelajaran yang diberikan oleh pendidikannya. Kalau boleh di pinjam pengetian profesi seorang dokter, yang tentu karena dia memiliki profesi yang berdasarkan ilmu, skill, dia dapat praktik untuk memberikan pengobatan pada manusia yang sakit. Guru juga memiliki profesi berdasarkan pengetahuan dan skillnya sebagai pengajar, memberikan praktik mengajar kepada peserta didik, agar peserta didik sebagai manusia pribadi memiliki kemampuan sesuai 
dengan ilmu yang dipelajari, bakat dan kemampuannya. Jadi guru dapat dikelompokkkan sebagai seorang yang memiliki profesi untuk diparaktikkan dalam mengajar peserta didik. Bahkan guru juga ketika dia mengejar profesinya sebagai guru, dia juga harus memproleh pelajaran praktik mengajar, PKL untuk memperdalam kemampuan praktiknya dalam mengajar agar ia layak disebut sebagai seorang guru yang memiliki profesi sebagai seorang guru. Dan selanjutnya dia akan mempraktikkkan profesinya sebagai pendidik pada lembaga pendidikan dimana dia bertugas. Jadi layak digolongkan sebagai sosok individu profesional yang menangani peserta didik untuk mencapai tujuan yang diharapkan, sebagaimana orang berobat ke dokter, berharap akan sehat.

Pendidik dalam pengertian sempit adalah mengajar, tetapi tugas seorang pendidik lebih luas luas dari itu, termasuk mengurus disiplin peserta didik, motivasi, kreativitas danlainnya yang berkaitan dengan pencerdasan peserta didik. Menurut Wikipedia, bahwa disiplin sekolah seperti standar berpakaian, ketepatan waktu perilaku sosial dan etika belajar/kerja. Namun sering terjadi pelanggaran disiplin, pelanggaran disiplin, sehingga terjebak dalam kesalahan perlakuan morak mapupun fisik. Dalam kaitannya dengan yang demikian seorang pendidik sebagai tenaga professional, dituntut untuk mampu mengatasi berbagai masalah pegelolaan kelas, khususnya dalam hal menjaga dan menciptakan kondidi serta situasi belajar peserta didik.

Adanya manajemen peserta didik profesional dalam praktik merupakan upaya untuk memberikan layanan yang sebaik mungkin kepada peserta didik semenjak dari proses penerimaan sampai saat peserta didik meninggalkan lembaga pendidikan ( sekolah ) karena sudah tamat/ lulus mengikuti pendidikan pada lembaga pendidikan ( sekolah ) itu. Fungsi manajemen peserta didik adalah sebagai wahana bagi peserta didik untuk mengembangkan diri seoptimal mugkin, baik yang berkenaan dengan individualitasnya, segi social, kreasinya, kebutuhan dan segi-segi potensi peserta didik lainnya. Agar tujuan dan fungsi manajemen peserta didik dapat tercapai, manajemen peserta didik profesional harus teraplikasi dalam praktik, dengan tetap memegang prinsip peraturan yang berlaku.

Pendidik sebagai seorang yang profesional dalam praktik harus mampu menyatukan berbagai ragam perilaku peserta didik untuk mencapai tujuan bersama, sukses ber- 
sama, dengan mengatur proses fungsi-fungsi manajemen, dengan tetap mendorong kemandirian peserta didik, agar mampu sebagai sosok individu yang mampu sebagai manusia individu yang mandiri, mahluk sosial, dan religius untuk menghadapi masa depan yang lebih baik.

\section{Simpulan}

Manajemen peserta didik profesional dalam praktik, merupakan sarana untuk membina, mengatur, merubah perilaku peserta didik sebagai objek menjadi manusia yang beriman, bertaqwa, serta memiliki kompetensi ilmu, pengetahuan dan skill, yang dapat merubah perilaku peserta didik ketika telah keluar atau selesai menempuh pendidikan di lembaga penddikan dimana mereka mencari sekolah mencari ilmu.

Peserta didik setelah keluar atau tamat dalam lembaga pendidikan dimana meraka bersekolah, statusnya berubah menjadi subjek yang diharapkan mandiri dalam menempuh kehidupannya, menghadapi kehidupan sosial yang jauh lebih komflek dari ketika mereka sebagai peserta didik. Itulah yang dapat dijadikan indikator apakah yang bersangkutan telah berhasil menerima pembinaan, pengajaran, bimbingan, selama menjadi pesera didik, ketika mereka mampu menyelamatkan diri dalam menempuh kehidupan yang lebih konflek bahkan ganas. Dalam hal ini manajemen peserta didik profesional dalam praktik, tidak menjadi ukuran, yang menjadi ukuran adalah kematangan peserta didik dalam membekali dirinya sebagai manusia yang mandiri.

\section{Daftar Pustaka}

Eka Prihatin. 2014. Manajemen Peserta Didik. Bandung: Alpabeta.

George R.Terry alih bahasa, Winardi. 1986. Asas-Asas Manajemen. Bandung: Alumni

Ramayulis dan Mulyadi. 2017. Manajemen \& Kepemimpinan Pendidikan Islam. Jakarta: Kalam Mulia.

Toto Tasmara. 2006. Spiritual Centered Leadership. Jakarta: Gema Insani. 
Tim Adminstrasi Pendidikan Universitas Pendidikan Indonesia, Manajemen Pendidikan, Penerbit Al pabeta, Bandung, Tahun 2012, halaman 204.

https:/ /azenismail.wordpress.com/2013/06/04/pengertian-profesi-danprofesionalisme/

https// Library.walisongo.ad.id “ Manajemen Profesionl “ (online ), diakses 27, Desember 2017.

https://www.kompasiana.com/ianmursito/profesionalisme-guru-sebagai-indikatorkeberhasilan-dalam-peningkatan-prestasi-belajarsiswa_576207d964afbdf5038b457e 